\title{
A value clarification on quality within Nursing Colleges in Gauteng
}

\author{
S Armstrong, MSc, Doctoral Student, RAU, Nursing Department \\ M Muller, D Cur, Professor of Nursing, RAU
}

\section{Abstract}

Quality assurance in higher education has been legislated. It is therefore necessary to develop a quality audit system for Nursing Colleges in Gauteng. The process of developing such a system is complex and needs to foster ownership by all the stakeholders. The first step in this process is to conduct a value clarification on quality. The purpose of this article is to explore and describe a value clarification on quality within the Nursing Colleges in Gauteng. An explanatory and descriptive qualitative research design was utilised. The results are grouped into structure, process and outcome values. Comparisons between the views of the different role-players are also presented. It is recommended that these results be utilised as the basis of a conceptual framework for the quality audit system for Nursing Colleges in Gauteng, as well as the development of quality indicators for Nursing Education Institutions in South Africa.

\section{Introduction}

Quality assurance is legislated in the Higher Education Act (South Africa, 1997). Therefore the management within a nursing college is responsible for evaluating the quality of services rendered. Externally the accreditation agent is also responsible for determining the quality of nursing education at nursing colleges. It is therefore necessary to develop a quality audit system for Nursing Colleges in South Africa. The study described in this article forms the first phase of a research project to develop a quality audit system for nursing colleges in Gauteng. Performance indicators will also be developed based on the values identified in this phase of the research. The performance indicators will in turn, be assembled into a quality audit tool. The first step in the development of a quality audit system is to conduct a value clarification on quality within the context of nursing colleges.

A value is "... the worth, desirability, or utility of a thing, or the qualities on which these depend (Thompson, 1995:1549). Popenoe (1977:571) has similar ideas and defines a value as Aan idea about what is good, right, wise or beneficial". McNally (in Hein \& Nicholson 1994:107) defines values as being beliefs that are important to us, or an enduring belief that a specific mode of conduct or state of existence is personally or socially preferable. She goes on to characterize a true value by the following criteria: it is prized and cherished, it is part of a pattern, freely chosen from among alternatives only after reflection and is positively affirmed and acted upon.

Social values are an integral part of every functional institution from family to large corporate business. Donabedian (1973:1) remarks that a characteristic of social values in a reasonably stable society is that they are largely implicit and that their influence on behaviour may easily escape notice. Nursing Colleges in Gauteng are currently in a difficult position as they are undergoing such profound change that institutionional values are not necessarily implicit and are certainly no longer explicit. Most colleges have mission statements and have, in the past engaged in some value clarification, but non of the colleges have retained their same roles of staffing base. This leads to doubt with regard to whether stated values are sufficiently pervasive upon which to base quality educational system. People's values change with ex-perience and maturity. An educational institution or any other company, for that matter, operates in complex circumstances and, as McNally (In Hein \& Nicholson, 1994:1090) puts it as follows: "Usually involve more than simple determination of right or wrong, good or bad, true or false. The conditions in which values work typically involve conflicting demands - a weighing and balancing - and finally an action that reflects a multitude of factors. Although everyone's value system in some degree is unique, an individual's values usually are grounded in the core values of the culture. "A company's vision of goals and values are central to the way in which it conducts business, or, as Lawson (In Walters. 1997:9) puts it, they express its spirit, life and soul. Values of personal responsibility for achievement, have to some extent been eroded by the egalitarian approach to politics, and fueled by the labour movement, which emphasizes equality of opportunity and rights of the masses rather than individual effort. It has, therefore, become most important to establish a set of values for the colleges and was an essential part of the research study. Without shared values, there will be no clear direction for the colleges. Values and value systems serve as standards which assist us to take positions on issues and form the basis upon which we can evaluate our own and other people's behaviour.

Values are common to many organizations, irrespective of their type and purpose. Manufacturing organizations put great emphasis now on customer service, and are, therefore, embracing values that were previously characteristic of service organizations such as reliability, value for money, accessibility, courtesy, integrity, recognition and reward, training and development. Victor Frankl as quoted in Covey (1994:74) simplifies the task of defining values by grouping them into three groups viz. Experiential values, or that which happens to us; creative values, or that which we bring into existence and attitudinal values, or our response in difficult circumstances. Stephen 
Covey (1994:24) refers to values as being maps in our heads of the way things should be as opposed to maps of the way things are, which Covey refers to as realities.

This was the starting point of the research study - to establish the way the customers believe the nursing colleges should be, rather than what they are currently and to ensure that the people working and studying at the colleges were consulted, thus encouraging ownership and relevance of the audit system to be developed. The phenomena being studied in this research were the values of the people associated with the nursing college in relation to quality nursing education. These values will be utilized as part of the conceptual framework for the development of a quality audit system in Nursing Colleges. The question therefore arises as to how the role players (internal and external outcomes) view quality within the context of nursing colleges in Gauteng. The purpose of this research is to conduct a value clarification on quality within the context of nurs- and important as a guide to conduct or state of existence.

Nursing College refers to a higher education institution which offers nursing programmes at basic and post-basic level in accordance to the statutory requirements laid down by the South African Nursing Council, funded by the Gauteng Provincial Administration.

Quality refers to the characteristics of excellence within the context of nursing colleges in Gauteng.

\section{Research design}

A qualitative research strategy was used which was exploratory and descriptive in nature. A qualitative design was chosen in order to develop insight and understanding into the values held by the internal and external customers of the nurs-

\section{Table 1: Distribution of population: Internal customers}

\begin{tabular}{|c|c|c|c|c|c|}
\hline College & Students & Lecturers & $\begin{array}{l}\text { Admin } \\
\text { Staff }\end{array}$ & Managers & Region/s served \\
\hline A & 1300 & 100 & 46 & 11 & $\begin{array}{c}\text { Central Wits \& } \\
\text { East Rand }\end{array}$ \\
\hline B & 1500 & 100 & 45 & 13 & $\begin{array}{l}\text { Soweto, West } \\
\text { Rand \& Vaal }\end{array}$ \\
\hline $\mathrm{C}$ & 950 & 65 & 33 & 11 & Pretoria \\
\hline $\mathrm{D}$ & 250 & 20 & 20 & 8 & $\begin{array}{c}\text { Pretoria, } \\
\text { neighbouring } \\
\text { Provinces } \\
\text { SADEC } \\
\text { countries }\end{array}$ \\
\hline TOTAL & 4000 & 285 & 144 & 43 & \\
\hline
\end{tabular}

\section{Table 2 : The planned sample}

\begin{tabular}{|c|c|c|c|c|c|c|}
\cline { 2 - 7 } \multicolumn{1}{c|}{} & \multicolumn{5}{c|}{ Internal customers } & \multicolumn{2}{c|}{ External customers } \\
\hline College & Students & Lecturers & $\begin{array}{c}\text { Admin. } \\
\text { Staff }\end{array}$ & Managers & Funders & Employers \\
\hline A & 6 & 4 & 4 & Members & & \\
\hline B & 6 & 4 & 4 & of & & \\
\hline C & 6 & 4 & 4 & Mx & & \\
\hline D & 6 & 4 & 4 & Comm. & & \\
\hline E & 6 & 4 & 4 & & & \\
\hline TOTAL & 30 & 20 & 20 & 19 & 5 & 11 \\
\hline
\end{tabular}

ing colleges in Gauteng, funded by the Gauteng Provincial Administration.

\section{Terminology}

A Value clarification refers to an analysis of the beliefs of roleplayers with regard to quality in a nursing college in Gauteng. A value is a freely chosen, cherished belief of what is desirable ing colleges in Gauteng and to derive meaning from the participants' perspective. De Vos $(1998 ; 242)$ states that in qualitative research, the researcher captures and discovers meaning once he becomes immersed in the data which was a necessary part of this research as it was essential to understand the data in the context of the restructuring nursing colleges. A value clarification is explored and described within the context of nursing colleges in Gauteng. The results are presented in quantitative 
format also, to add meaning and easier comparison between role-players.

\section{Population and sampling}

The population for this research were the internal and external customers of the four nursing colleges funded by the Gauteng Provincial Administration which will remain in Gauteng after the restructuring process is complete. The research study is being conducted within a business excellence framework. In terms of business excellence, the customer is the final arbiter of product and service quality, and it is customary to separate customers into internal and external customers. The term customer can be defined as " ... anyone to whom a product or service is provided." (West-Burnham, 1997:41). When applied to service organizations such as educational institutions, it is more difficult. Green (1995:16) debates this issue saying: "Who is the customer in higher education? It is the service user (the students) or is it those who pay for the service (the govern- affected by it." External customers were those who were associated with the college but were not directly employed by the college or studying at the college. The following inclusion criteria are set:

- $\quad$ an ability to communicate in writing in English or Afrikaans:

- had sufficient exposure to a nursing college (a minimum of one year) to internalize an opinion regarding quality in a nursing college;

- have given consent to inclusion.

Internal customers had to be either enrolled at one of the nursing colleges (students) or employed by one of the nursing colleges in Gauteng. The latter group was divided into managers who occupied the rank of assistant director or above, or were acting in this rank, administrative staff and nurse lecturers. External customers were divided into the following groups:

\section{Table 3: Sample realization}

\begin{tabular}{|c|c|c|c|c|c|c|}
\cline { 2 - 7 } \multicolumn{1}{c|}{} & \multicolumn{5}{c|}{ Internal customers } & \multicolumn{2}{c|}{ External customers } \\
\hline College & Students & Lecturers & $\begin{array}{c}\text { Admin. } \\
\text { Staff }\end{array}$ & Managers & Funders & Employers \\
\hline A & 6 & 4 & 4 & Members & & \\
\hline B & 6 & 4 & 4 & of & & \\
\hline C & 6 & 4 & 4 & $M x$ & & \\
\hline D & 6 & 4 & 4 & Comm & & \\
\hline E & 6 & 4 & 4 & & & \\
\hline TOTAL & 30 & 20 & 20 & 19 & 5 & 11 \\
\hline
\end{tabular}

The eight employees included :

Academic hospitals: $\quad 3$

Speciality hospitals: 1

Regional services: $\quad 2$

Private sector : 2

ment, the employers)? Is the student the consumer, the product or both? ...While it may be relatively easy to identify the physical needs of students in higher education in terms of access to adequate library provision and adequate student accommodation, the heart of the education service is the relationship between the lecturer and the student in the teaching and learning process. Unlike the manufacturing industry, the producers and customers (lecturers and students) are both part of the production process."

As a result of the difficulty in separating students and lecturers from the "production process" the staff of the colleges were grouped as internal customers in line with Lewis and Smith's (1994:320) definition of a stakeholder, that is “ . ... an individual or department who either has an effect on the process or is
- $\quad$ Funders of the colleges, who, in this case are the managers/directors in the Gauteng Health Department. In order to be included in the sample, they had to have a decision-making role with regard to the allocation of funds to the colleges.

- Potential employers of the graduates of the college. In order to be included, they had to be managers who have a direct role in recruiting and/or employing nurses in their institutions. A mix of private and public institutions were chosen to ensure representivity.

- Health care consumers were also recognized as external customers. The purpose of this study group was very broadly defined as members of the community on the assumption that all members of the community have, or may in the future, require the services of the 
products (graduates) of the nursing colleges.

\section{Sampling method}

The sampling method in relation to the internal and external customers is described.

\section{Internal customers}

The students in this study were sampled by means of stratified ingfully. A post basic group was selected at the fourth college as this college will be offering post basic courses only. All racial groups were included in this sample. The one cultural group not included in the first cluster was white English speaking students. As a result purposive sampling of a group of these students were selected from a fifth college targeted for closure but still training third and fourth year students. Once the responses were received, random sampling of the units (see results) was done to ensure a manageable number of units, which was sufficient to ensure a likelihood of saturation being

\section{Table 4: Coding system for value clarification}

\begin{tabular}{|l|l|}
\hline THEMES, CATEGORIES \& SUB-CATEGORIES & CODE \\
\hline 1. STRUCTURE & $\mathrm{S}$ \\
\hline 1.1. Human Resources & $\mathrm{SH}$ \\
\hline 1.2. Material/physical resources \& structures & $\mathrm{SM}$ \\
\hline 1.3. Technology & $\mathrm{ST}$ \\
\hline 1.4. Theoretical learning facilities & $\mathrm{SL}$ \\
\hline 1.5 Practical learning facilities & $\mathrm{SP}$ \\
\hline 1.6. Strategy & $\mathrm{SS}$ \\
\hline 2. PROCESSES & $\mathrm{P}$ \\
\hline 2.1. Leadership & $\mathrm{PL}$ \\
\hline 2.1.1. Policy development & $\mathrm{PLP}$ \\
\hline 2.1.2. Human resource management & $\mathrm{PLH}$ \\
\hline 2.1.3. Management ethics & $\mathrm{PLE}$ \\
\hline 2.2. Educational programme & $\mathrm{PE}$ \\
\hline 2.2 .1$. Organization & $\mathrm{PEO}$ \\
\hline 2.2.2. Content & $\mathrm{PEC}$ \\
\hline 2.2 .3$. Presentation & $\mathrm{PEP}$ \\
\hline 2.2.4. Evaluation & $\mathrm{PEE}$ \\
\hline 2.2 .5 . Extra-curnicula activities & $\mathrm{PEX}$ \\
\hline 2.3. Relationships & $\mathrm{PR}$ \\
\hline 2.3.1. Internal customers & $\mathrm{PRI}$ \\
\hline 2.3.2. External customers & $\mathrm{PRE}$ \\
\hline 2.4. Research & $\mathrm{PS}$ \\
\hline 3. RESULTS & $\mathrm{R}$ \\
\hline 3.1. Community outreach & $\mathrm{RC}$ \\
\hline 3.2. Products of the college & $\mathrm{RP}$ \\
\hline 3.3. Organizational development & $\mathrm{RD}$ \\
\hline 3.4. Recognition in the community & $\mathrm{RR}$ \\
\hline
\end{tabular}

sampling. The strata identified were firstly students registered at the four nursing colleges which will remain after restructuring and with whom the audit system will be developed. The other clusters identified were cultural groups, year of study and basic or post-basic courses. With regard to the first stratum, one group of students from each of the four colleges, who were attending college blocks at the time of data collection, was selected. Of the students registered at the colleges, one second year, one third year and one fourth year

group of basic students was selected, each from a different college, who were available to the researcher at the time. First year students were not selected as they would not have had sufficient exposure to the nursing college to participate mean- achieved, was analysed. The following sample was selected:

- $\quad$ College A - Fourth year student nurses (Afrikaans speaking white students and two coloured students).

- $\quad$ College B - Second year student nurses (black and white Afrikaans speaking)

- $\quad$ College C - Black students

- $\quad$ College D - only white English speaking student's re -sponses used.

- $\quad$ College E - Mixed racial group of post basic students mainly black.

Six responses were randomly selected from the total of each college's responses - a total of 30 responses in all. This proved 
sufficient to reach saturation for this stratum (see table one)

The nurse lecturers and administrative staff were selected by means of purposive sampling by the manager of each of the selected institutions to ensure that all cultural groups were included in the sample. By engaging the managers to conduct the purposive sampling, researcher subjectivity was reduced. The manager's responses were solicited directly by the researcher. All members of the management committee of the Gauteng Nursing Colleges, present at a management committee meeting were included in the sample. This included 19 managers - both nurse managers and registrars. All responses were analysed.

\section{External customers}

The funders were selected by means of purposive sampling. The line managers responsible for nursing education were selected from Chief Director to Deputy Director level. In addition the Chief Directors of Finance and Strategic Management respectively were selected as they have a profound influence on funding decisions related to the nursing colleges. A total of 5 funders were therefore included. The employers were sampled by a colleague of the researcher to avoid subjectivity by means of stratified sampling. Strata included academic hospitals, regional and district health facilities, private clinics and speciality hospitals. Eleven employers agreed to participate but only eight returned their questionnaires. A summary of the planned

\section{Table 5: Number of responses per category/sub-category}

\begin{tabular}{|c|c|c|c|c|c|c|c|c|}
\hline \multirow[b]{2}{*}{ Themes, categories \& sub-categories } & \multicolumn{2}{|c|}{$\begin{array}{c}\text { Students } \\
\mathrm{n} 30\end{array}$} & \multicolumn{2}{|c|}{$\begin{array}{c}\text { Lecturers } \\
n 17\end{array}$} & \multicolumn{2}{|c|}{$\begin{array}{c}\text { Adm. Staff } \\
\text { n20 }\end{array}$} & \multicolumn{2}{|c|}{$\begin{array}{c}\text { Man agers } \\
n 19\end{array}$} \\
\hline & $\mathrm{cf}$ & Sf & cf & sf & $\mathrm{cf}$ & sf & cf & sf \\
\hline \multicolumn{9}{|l|}{ 1. STRUCTURE } \\
\hline 1.1. Human Resources & 13 & 11 & 16 & 10 & 6 & 6 & 9 & 7 \\
\hline 1.2. Material resources \& struclures & 9 & 8 & 6 & 6 & 10 & 10 & 6 & 5 \\
\hline 1.3. Technology & 2 & 2 & 8 & 7 & 9 & 8 & 4 & 4 \\
\hline 1.4. Theoretical leaming facilities & 9 & 9 & 7 & 7 & 7 & 6 & 5 & 4 \\
\hline 1.5. Practical leaming facilities & 5 & 5 & 2 & 2 & 0 & 0 & 4 & 4 \\
\hline 1.6. Strategy & 8 & 5 & 2 & 2 & 1 & 1 & 7 & 6 \\
\hline \multicolumn{9}{|l|}{ 2. PROCESSES } \\
\hline \multicolumn{9}{|l|}{ 2.1. Leadership } \\
\hline 2.1.1. Policy development & 14 & 12 & 4 & 4 & 1 & 1 & 8 & 5 \\
\hline 2.1.2. Human resource management & 3 & 2 & 23 & 14 & 16 & 9 & 21 & 11 \\
\hline 2.1.3. Management ethics & 14 & 9 & 6 & 4 & 1 & 1 & 2 & 2 \\
\hline \multicolumn{9}{|l|}{ 2.2. Educational Programme } \\
\hline 2.2.1. Organization & 16 & 10 & 1 & 1 & 0 & 0 & 0 & 0 \\
\hline 2.2.2. Content & 13 & 9 & 1 & 1 & 1 & 1 & 3 & 3 \\
\hline 2.2.3. Presentation & 20 & 16 & 0 & 0 & 0 & 0 & 2 & 2 \\
\hline 2.2.4. Evaluation & 5 & 5 & 0 & 0 & 0 & 0 & 3 & 3 \\
\hline 2.2.5. Extra-curncula activities & 5 & 5 & 0 & 0 & 0 & 0 & 1 & 1 \\
\hline \multicolumn{9}{|l|}{ 2.3. Relationships } \\
\hline 2.3.1. Internal customers & 31 & 18 & 8 & 7 & 4 & 4 & 4 & 4 \\
\hline 2.3.2. External customers & 3 & 3 & 3 & 3 & 4 & 4 & 1 & 1 \\
\hline 2.4. Research & 0 & 0 & 6 & 4 & 1 & 1 & 4 & 4 \\
\hline \multicolumn{9}{|l|}{ 3. RESULTS } \\
\hline 3.1. Community outreach & 2 & 1 & 4 & 4 & 0 & 0 & 4 & 4 \\
\hline 3.2. Products of the college & 10 & 9 & 10 & 9 & 5 & 5 & 12 & 8 \\
\hline 3.3. Organizational development & 15 & 9 & 17 & 8 & 4 & 4 & 12 & 8 \\
\hline 3.4. Recognition in the community & 5 & 4 & 2 & 2 & 3 & 3 & 4 & 4 \\
\hline
\end{tabular}

$\mathrm{cf}=$ category frequency i.e the number of times a particular value was cited

$\mathrm{sf}=$ Sample frequency i.e the number of respondents who cited a particular value 
sample of this study is shown in table two.

Community/political viewpoints were extracted from white papers and government regulations relating to higher education and public sector service delivery, education and training, published since 1994. The assumption was that sufficient consultation had occurred in the process of drawing up these documents. The following publications were included:

- The white paper on Public Service Training and Education (July 1997).

- The white paper on Higher Education (Notice 712 of 1997 published in Government Gazette, Vol. 382, No. 17944,18 April 1997). published in Government Gazette, Vol. 388, No. 183490, 1 October 1997).

- The South African Qualifications Authority Act, (Act No. 58 of 1995).

- The Nursing Act (No. 50 of 1978), as amended by No. 5 of 1995 and No. 19 of 1997.

- $\quad$ The Skills Development Bill (B81 of 1998).

\section{Data collection}

Data for this research was collected in the form of naive sketches (spontaneous freely written views/perceptions on the phenomena), in the case of the funders an interview was conducted, as

\section{Table 6: Relative importance of values to internal customers expressed as percentages of the total sample}

\begin{tabular}{|c|c|c|c|c|c|}
\hline & Stud & Lect. & $\begin{array}{c}\text { Admin } \\
\text { Staff }\end{array}$ & Manag & Average \\
\hline \multicolumn{6}{|c|}{ Themes, categories \& sub-categories } \\
\hline \multicolumn{6}{|l|}{ 1. STRUCTURE } \\
\hline 1.1. Human Resources & 37 & 59 & 30 & 37 & 40 \\
\hline 1.2. Ma terial resources \& structures & 27 & 35 & 50 & 26 & 34 \\
\hline 1.3. Technology & 7 & 41 & 40 & 21 & 24 \\
\hline 1.4. Theoretical leaming facilities & 30 & 41 & 30 & 21 & 30 \\
\hline 1.5. Practical leaming facilities & 17 & 12 & 0 & 21 & 13 \\
\hline 1.6. Strategy & 17 & 12 & 5 & 32 & 16 \\
\hline \multicolumn{6}{|l|}{ 2. PROCESSES } \\
\hline \multicolumn{6}{|l|}{ 2.1. Leadership } \\
\hline 2.1.1. Policy development & 40 & 24 & 5 & 26 & 26 \\
\hline 2.1.2. Human resource management & 7 & 82 & 45 & 58 & 42 \\
\hline 2.1.3. Management ethics & 30 & 23 & 5 & 11 & 19 \\
\hline \multicolumn{6}{|l|}{ 2.2. Educational Programme } \\
\hline 2.2.1. Organization & 34 & 6 & 0 & 0 & 13 \\
\hline 2.2.2. Content & 30 & 6 & 5 & 16 & 16 \\
\hline 2.2.3. Pre sentation & 53 & 0 & 0 & 11 & 21 \\
\hline 2.2.4. Evaluation & 17 & 0 & 0 & 16 & 9 \\
\hline 2.2.5. Extra-curricula activities & 17 & 0 & 0 & 5 & 7 \\
\hline \multicolumn{6}{|l|}{ 2.3. Relationships } \\
\hline 2.3.1. Internal customers & 60 & 41 & 20 & 21 & 38 \\
\hline 2.3.2. External customers & 10 & 18 & 20 & 5 & 13 \\
\hline 2.4. Research & 0 & 24 & 5 & 21 & 11 \\
\hline \multicolumn{6}{|l|}{ 3. RESULTS } \\
\hline 3.1. Community outreach & 3 & 24 & 0 & 21 & 11 \\
\hline 3.2. Products of the college & 30 & 53 & 25 & 42 & 36 \\
\hline 3.3. Organizational development & 30 & 47 & 20 & 42 & 36 \\
\hline 3.4. Recognition in the community & 13 & 12 & 15 & 21 & 11 \\
\hline
\end{tabular}

The white paper on transformation of Further Education and Training (Notice 2188 of 1998 published in Government Gazette, Vol. 399, No. 19281, 25 September 1998).

- The white paper on transforming Public Service Delivery (Batho Pele white paper) (Notice 1459 of 1997 well as by means of document analysis (policies, legislation, mission statement, etc) in the case of the community values. In both the naive sketches and the interviews, one open ended question was posed in the form of a statement to be completed, viz: I believe a quality nursing college is one that .... The researcher explained the purpose of the research and solicited 
the co-operation and consent of the student participants and the managers personally and in person, and telephonically from the employers. The managers did this on the researcher's behalf. The decision to interview the funders rather than ask for a completed questionnaire was done to save the funders time and also to ensure that their views of all the selected participants were obtained, in view of the small size of the sample for this group. The same questions were posed to the funders, but their responses were tape recorded and a verbatim transcript was made. Data from the community was collected by transcribing the values expressed in the aims, objectives, goals, vision. purpose, and/or principles, as they appeared in each document.

\section{Data analysis}

Data was analyzed by means of a content analysis according esses" theme (allocated the letter P), the L "Leadership" category (allocated L) and the "policy development" sub-category (allocated the letter P).

\section{Trustworthiness}

Guba's model (Lincoln and Guba, 1985) to ensure trustworthiness was applied. The principles described in this model are truth value, applicability, consistency and neutrality. The following measures were applied:

- The researcher has had prolonged engagement in nursing education, i.e. a total of 16 years of direct involvement in nursing colleges in Gauteng and therefore understands the structure and dynamics of the nursing colleges and the nursing education community.

- $\quad$ The naive sketches were deliberately sought from a variety of groupings of involved persons to ensure

\section{Figure 1: A comparison of structure values}

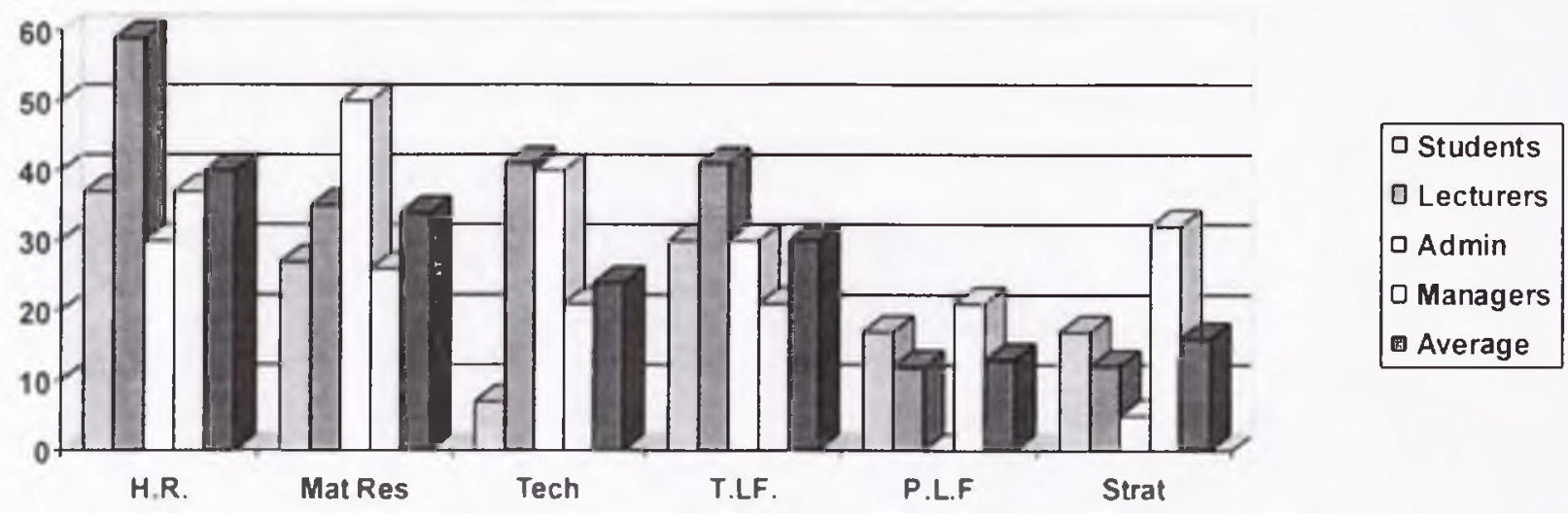

to the steps as described by Tesch (1990:142-145) for open coding. A modification of Tesch was introduced to include the Donabedian (1969) themes of structure, process and results. The eight steps was carried out on each separate set of responses, i.e. the students', the managers', tutors' and the administrative staffs' responses. Results from each coding exercise were compared and similar categories from the different sets of data were clustered and renamed to form common, homogenous categories. The entire set of responses was then re-coded using the final set of categories to ensure that the coding system was appropriate and relevant. Each naive sketch was allocated a number for identification purposes. Student responses were designated $\mathrm{S}$ followed by an individual number, Managers M, Tutors (lecturers) $\mathrm{T}$ and administrative staff $\mathrm{A}$. Themes, categories and sub-categories were developed. The codes used reflected these. For

example, a value coded "PLP" indicates it belongs to the "Proc- representivity and informed participation.

- The results of the internal customers were compared with those of the external customers as a means of ensuring applicability.

- Two external coders were used to verify the analysis and development of the categorization system and to ensure neutrality. An audit trail was left for confirmability.

\section{Results of the study}

The results are presented with reference to the sample realisation and the findings on the value clarification (structure, process and results). Lastly the responses between the internal and external customers are compared with one another and graphically presented. 


\section{Sample realization}

The planned sample included only the four nursing colleges which will remain after restructuring, however, it was necessary to include a fifth college in order to include the white English speaking cultural group to ensure representivity of all cultures. During the analysis of the lecturers' responses, an insufficient number of the lecturers at two of the colleges had submitted substantial contributions. As both colleges were in the Pretoria area, and the staff from those two colleges were in recess at the time of analysis, an additional Pretoria College was included for this purpose. The realization of the sample is displayed in table three.

\section{Findings: value clarification}

Three themes were identified viz. Structure. processes and results. This categorization is supported by the Donabedian model (1969 and 1980), quoted by both Muller (1996:228-230) and Ball (1991:20).

Structure described " ... all the resources needed to provide a service of the desired standard and included all aspects of the
In addition, three of the categories were subdivided into subcategories as shown in table four.

\section{Description of categories}

The following categories were developed: structure values, process and result/outcome values.

\section{Structure values}

The following structure-related values were identified: human resources, material/physical resources, technology, theoretical learning facilities, practical learning facilities and strategy (see table four and the coding system applied).

\section{Human resources}

The term human resources refer to the staff that is required to provide the services of the college. In developing this category, the aspects that were cited as important in a quality college related to the level of staff motivation, their competency, which included qualifications for the job. their personal qualities and the provision of staff.

\section{Figure 2: A comparison of leadership values}

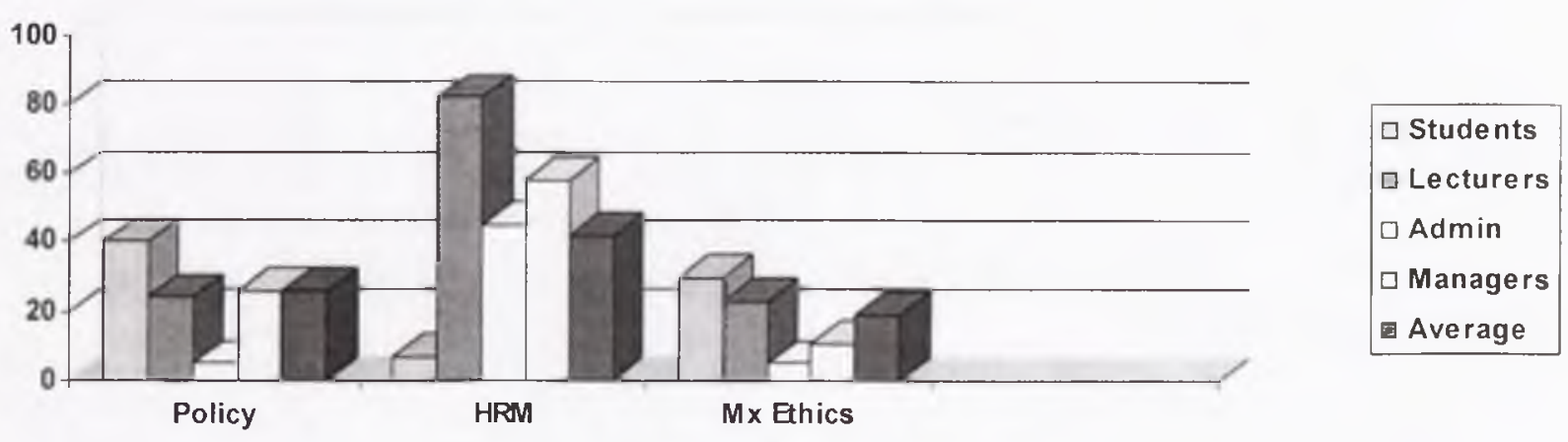

physical environment in which (education) takes place, the resources available in terms of the number and degree of skill of the staff, the equipment available." (Ball 1991:20). It also includes laws that govern the functioning of the institution. Muller (1996:228) explains structure as “... what is required for the performance of an action ... the support system. It refers to the physical environment or organizational set-up." Process describes step by step how an action ... should be performed (Muller 1996:229). Ball (1991:20) explains it as Aincluding all the interactions within a service, the sequence of events, their time-scale and the technical and interpersonal quality of the service, or, all events, interactions and interventions between a service and its clients. Results or outcomes refer to changes in the institution that can be attributed to the structure and/or the processes. A total of fourteen categories were developed.

\section{Physical resources}

This category includes all materials and structures that a college requires in order to function. Respondents referred mainly to the types of resources required including a library, telephones, transport and a tea-room, the management of those resources. and the physical environment including aesthetics and security.

\section{Technology}

This refers to mechanical and/or electrical equipment that can be used to improve efficiency in the college. Respondents also referred to types here, for example, computers, shredders, teaching aids, photocopy machines and faxes. Accessibility to the technology was important both in terms of gaining physi- 
cal access and ease of use, but also having the knowledge to utilize the equipment. Many respondents also referred to the necessity of utilizing technology to improve efficiency in the college.

\section{Theoretical leaning resources}

Learning resources that were useful in assisting theoretical learning were included in this category. Almost all of the respondents for this category referred to the library as an important learning resource, and specifically the types, amount, recency, accessibility and appropriateness of the books that

\section{Process values}

The following process-related values relate to leadership, educational programme, relationships and research. Sub-categories were identified in the first three (see table four).

\section{Leadership}

Leadership is taken to mean the influence of subordinates by superiors in order to persuade them to pursue the goals of the organization actively and effectively (Gerber, 1990:272). Subcategories were identified in relation to policy development,

\section{Figure 3: A comparison of educational programme}

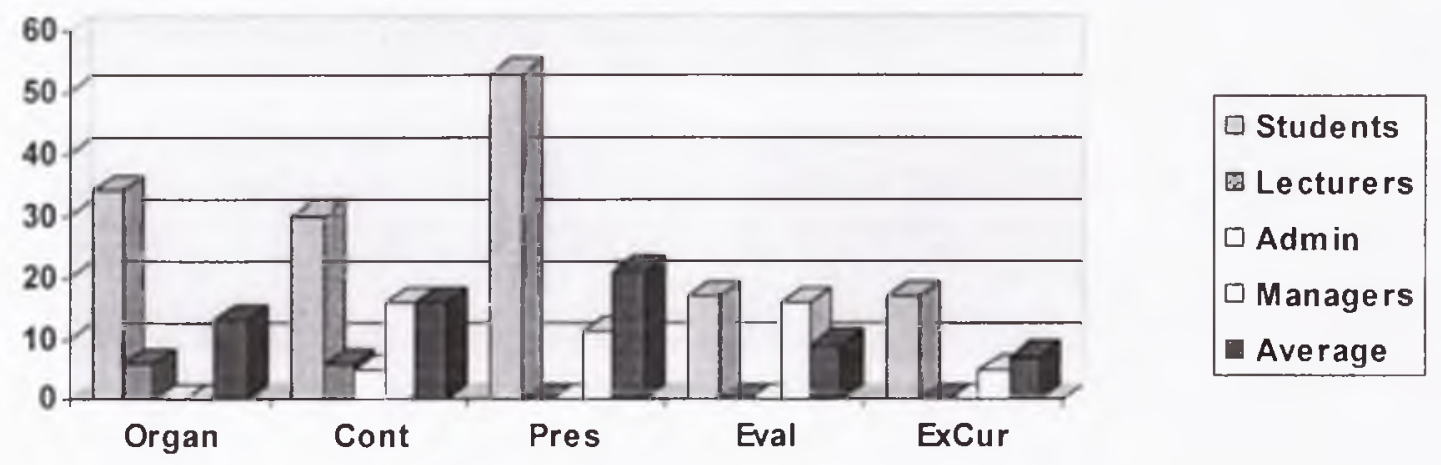

should be stocked. Other resources mentioned were models, and computer programmes. Some learning resources were classified under the technology category.

\section{Practical learning resources}

Learning resources that were useful in assisting practical or skills acquisition were included in this category. The clinical skills laboratory, the hospitals and the other clinical sites and the clinical department (an academic department) were mentioned. Little detail was given and answers were, on the whole quite vague.

\section{Strategy}

The term strategy is used here to indicate the formulation, implementation and evaluation of actions that will enable the college to achieve its objectives. (Fox, 1991 as quoted in Van der Waldt, 1997:282). It is included as part of structure as the college could not function without these guidelines. Some commented on the way strategy should be developed, but most of the respondents referred to the necessity of including principles of transformation in the strategy. Aspects such as racial equality, tolerance and fairness were mentioned. Quality was cited to be a necessary outcome of the strategic plan. human resource management, management ethics, education programme, organization, content, presentation, evaluation, extra-curricula activities, relationships, internal customers, external customers and research.

\section{- Policy development}

The responses that were classified under this category referred mainly to the development of policy or what the respondents would like to be policy, rather than referring to existing policy. The colleges are currently in the process of being restructured and therefore are undergoing profound change in terms of policy which probably explains the responses. As a result policy development was placed as a process rather than structure of which, once finalized, it will eventually become part. The three main aspects identified were governance including the processes and the structures of governance which should exist, institutional culture which included transformation issues, discipline, language medium, and control mechanisms. Access was the third issue referred to and related to access of the staff and students to various facilities and other staff members as well as access of new recruits i.e. selection.

\section{- Human resource management}

Human resource management is taken to mean the purposeful actions aimed at optimally providing, using, remunerating, developing and maintaining trained motivated personnel who will meet the goals of the organization. The aspects identified by 
the respondents were placement and utilization of staff, interpersonal and labour relations and staff development. The interpersonal and labour relations sub-categories included fairness, motivation, trust, teamwork, working hours, and support. Staff development included access or availability to opportunities for development, orientation, the content of staff development programmes and evaluation/assessment.

- Management ethics

This term refers to Athe motivational means which direct the behaviour and conduct of personnel (van der Waldt, 1997:40). Three aspects were identified in this category, viz. accountability, values and conduct.

\section{Educational programme}

The education programme referred to the curriculum in its broadest sense, or aspects of teaching and learning. The following sub-categories emerged: organization, content, presentation, evaluation and extra-curricular activities.

\section{Figure 4: Relationships and research}

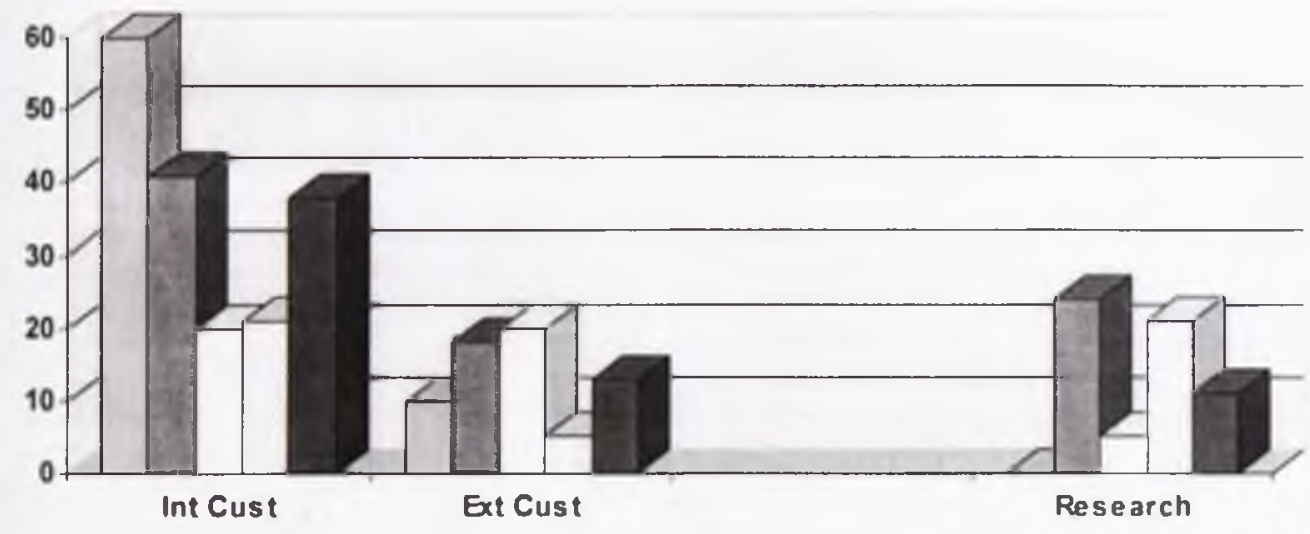

\section{Figure 5: A comparison of results/ outcome values}

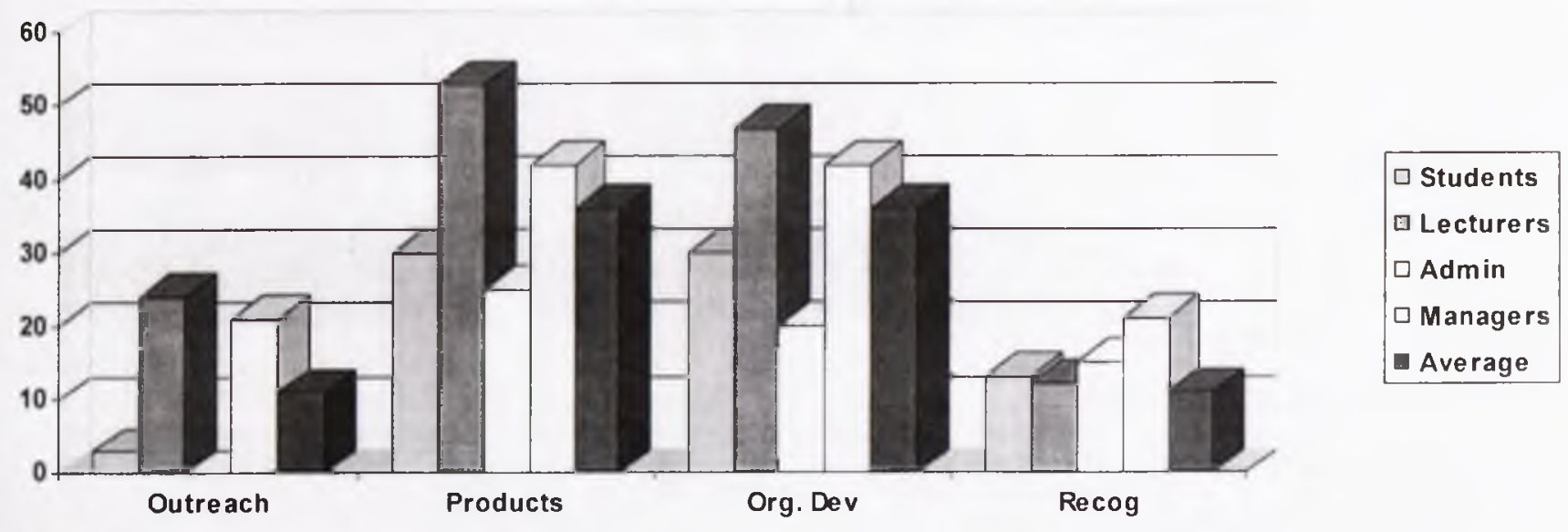


In this category, respondents discussed how the organization of the programme such as the way lecture periods were structured, would influence the quality of the college. Respondents emphasized the principle that the organization of the programme should enhance learning opportunities. Ways of doing this were to ensure that consideration was given to timing of study blocks to ensure they correlated with practica and allowed sufficient time to study for examinations. A balance between self-study and contact with lecturers was important. And the optimum utilization of the available time.

\section{- Content}

With regard to the content of the curriculum, or what is taught at the college, the important aspects were that it should be relevant to the learner and the community she will serve, and it should be outcomes based.

\section{- $\quad$ Presentation}

Presentation refers to the way in which lecturers present the subject matter in the curriculum. Adequate preparation on the part of the lecturers, language medium, student centeredness. utilization of lecturers from outside the college in addition to college lecturers, flexibility, variety and creativity were all suggested as being important. Utilization and appropriateness of prescribed books was also mentioned by several respondents. One remarked that lecturers should aim at teaching for excellence rather than competency.

\section{- Evaluation}

Evaluation of the curriculum and the students was mentioned Examination regulations, standards of evaluation, and effi-

\section{Figure 6: Comparison of average sample frequency per category}

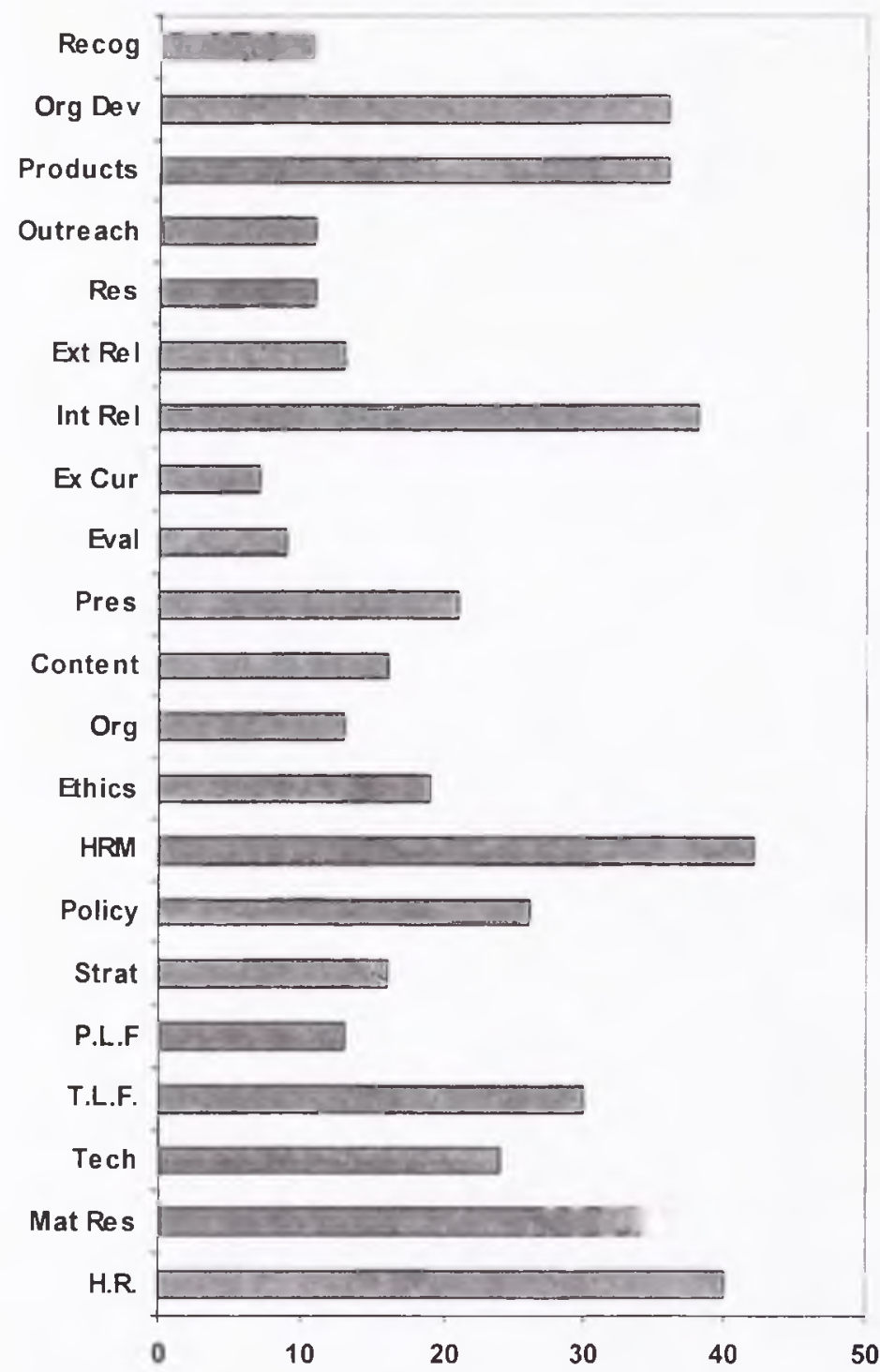

ciency of the evaluation system were mentioned.

\section{- Extra-curricula activities}

This category refers to activities that are not included in the formal curriculum. They may take place within or outside the college but involve the staff and students of the college. They are considered to be important to reduce stress and to improve creativity. Activities mentioned included sport of several types, concerts, contact with other colleges, motivational seminars and tours.

\section{Relationships}

The word relationship here means a connection or association between people having dealings with one another. The following sub-categories emerged: internal customers and external customers.

- Internal customers

- $\quad$ For the purpose of this study, internal customers of the nursing colleges are considered to be the staff (management, administrative and lecturing staff) and the students. Involvement of all groups of internal customers in the deci sion-making and information sharing in the college. The importance of relationships with a student counselor/lecturer or mentor both with regard to personal and academic support was mentioned several times. Accepted codes of behaviour, or precepts, with regard to com munication such as confidentiality, mutual re spect, being non-judgmental, availability and helpfulness were all mentioned with regard to relationships. The need to improve trans-cultural understanding was also noted. 
External customers are the people and groups of people who are associated to the college but are not part of its infrastructure. This definition was not given to respondents who referred to hospital staff, parents, previous graduates of the college, and members of the community. All these were included in this category. Most responses in the category were vague indicating simply that relationships with the above-mentioned persons should be improved or be good, assuming this would assist in creating a quality college but not indicating specifically how the college would benefit. general terms is important for a quality college.

\section{Results/outcome values}

The values related to results are grouped into community outreach, products of the college, organizational development and recognition in the community (see table four).

\section{Community outreach}

Community outreach refers to the college staff and students

\section{Figure 7: Comparison of category frequency}

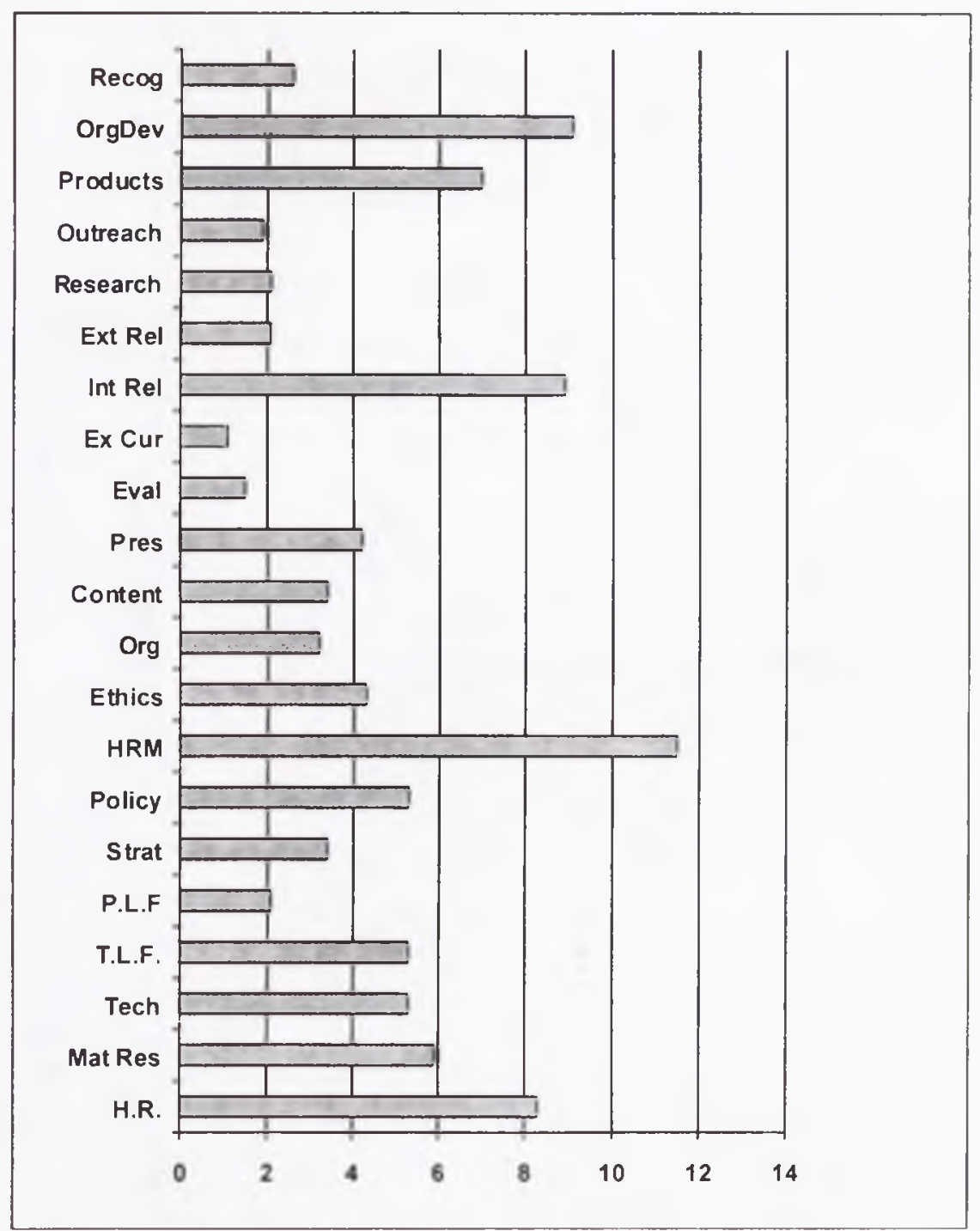

\section{Research}

Research is defined as the systematic enquiry that uses orderly methods to answer questions or solve problems. In this category most of the respondents identified the importance of lecturers having the opportunity to do research, either formally or to keep up to date with changes, or, that research. in very efforts to go into the community and assist the community, or to encourage the community to have access to the college. This included giving an opportunity to health care personnel not registered as students of the college to benefit from college programmes, participation in community development projects, being part of a community in order to be aware of the 
needs of the community and teach appropriately, as well as to gain credibility amongst the community.

\section{Products of the college}

- $\quad$ Products in this context refer to students who have were, firstly that the graduated of the college are able to be deliver a comprehensive nursing service in health care facilities anywhere in the world. Secondly the graduates should possess certain abilities, personal qualities and values on completion of training at a quality college. These included competency, confidence,

\section{Results- Values of external customers}

Figure 8:Structure values of external customers

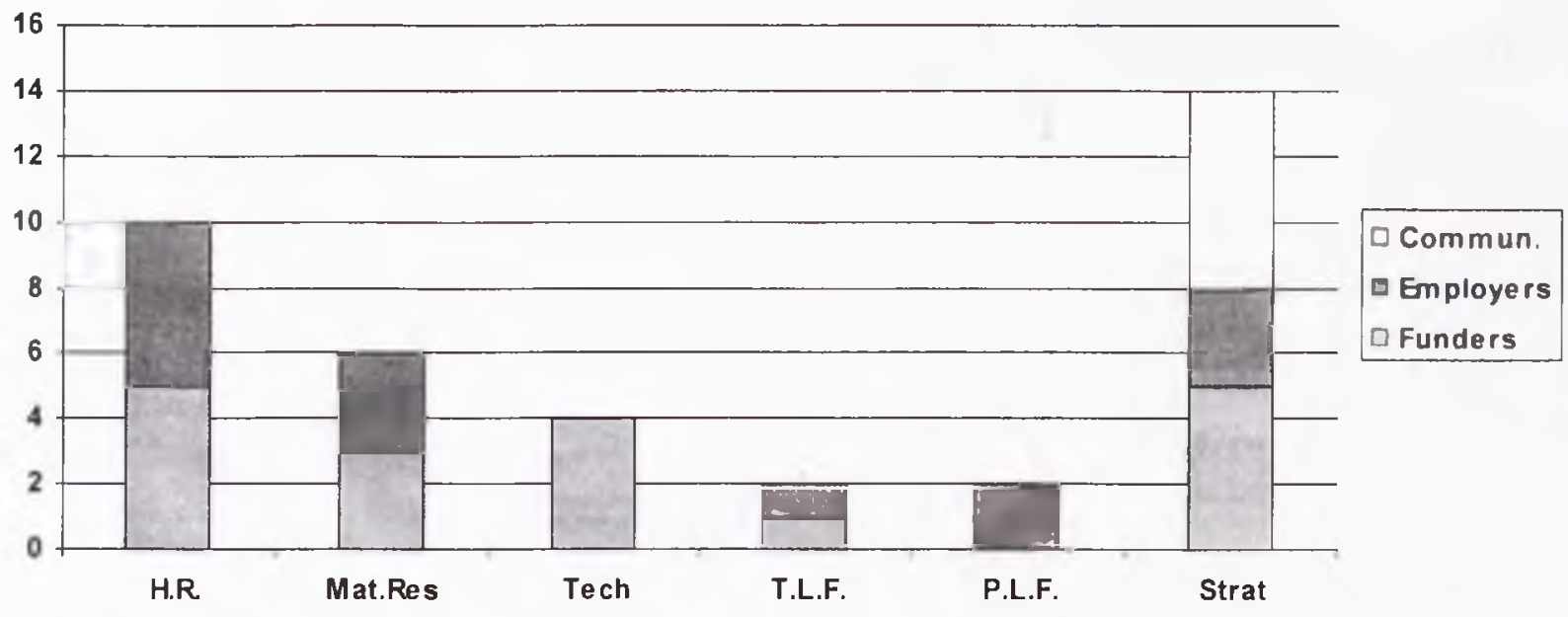

Figure 9: Leadership values of external customers

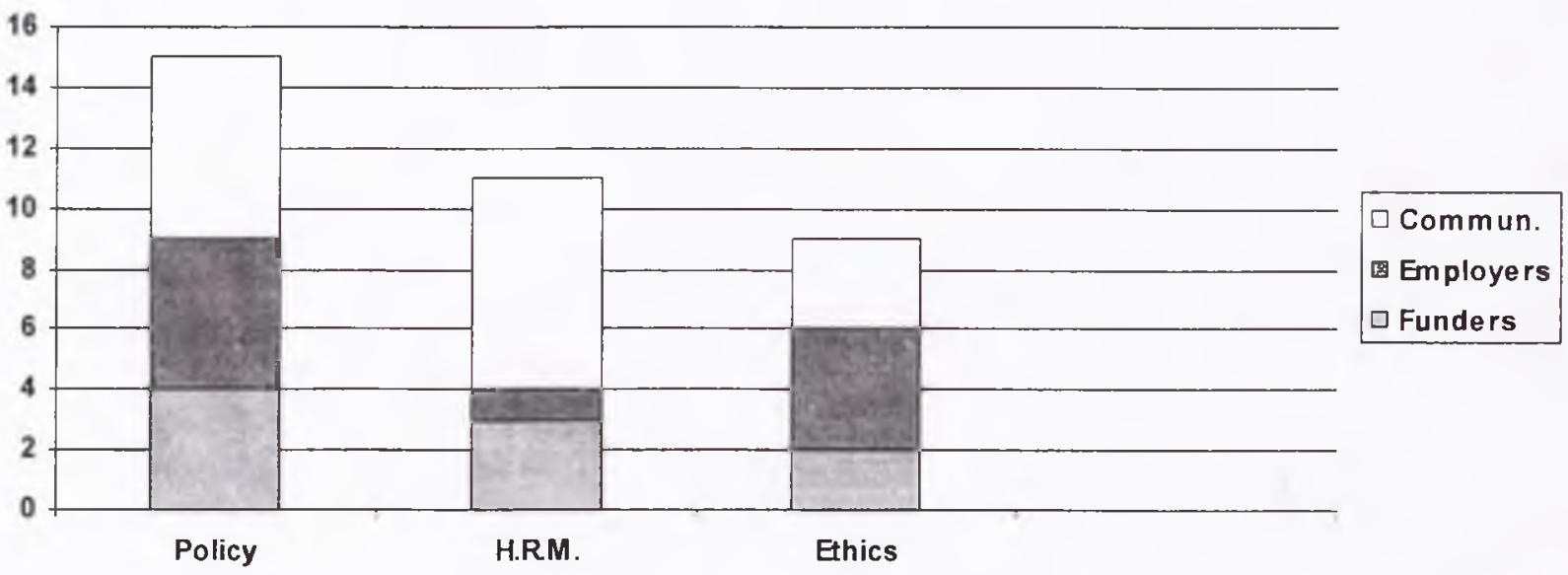

completed courses and qualified from the college or academic products. Only one respondent referred to products other than those in the definition above, and then in vague terms as a service. Community development projects categorized above could be considered to be a product. The sub-categories identified among the academic products caring, honesty, devotion, adaptability, professionalism, patience, knowledgeable, and assertiveness.

\section{Organizational development}

This term refers to a systematic, planned effort to bring about 
change in the institution@ (mercer, 1991:7 in van der Waldt, 1997:288). Included in this category were units referring to values (particularly with regard to transformation), communication, quality control, conflict management and teamwork. all of which are used to bring about or fuel change in the organization.

\section{Recognition in the community}

This category refers to acknowledgment of people and groups outside the college that it is a quality college. The sub-catego-

\section{Comparison of responses}

The results of the internal and external customers are compared with one another and graphically presented.

\section{Internal customers}

Table five indicates the number statements (of or category frequency) made by internal customers classified according to each of the identified categories and sub-categories. As some respondents cited more than one example in a particular cat-

\section{Figure 10: Educational programme, relationships and results- values of external customers}

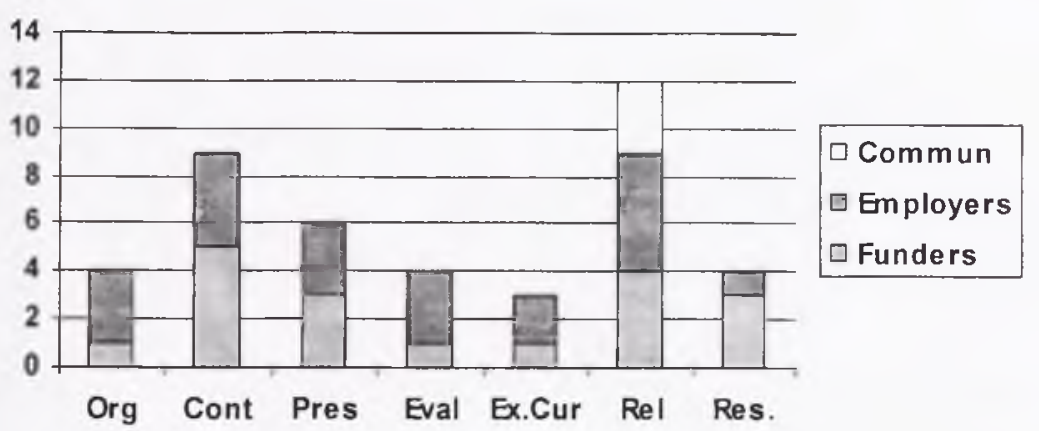

\section{Figure 11: Results- values of external customers}

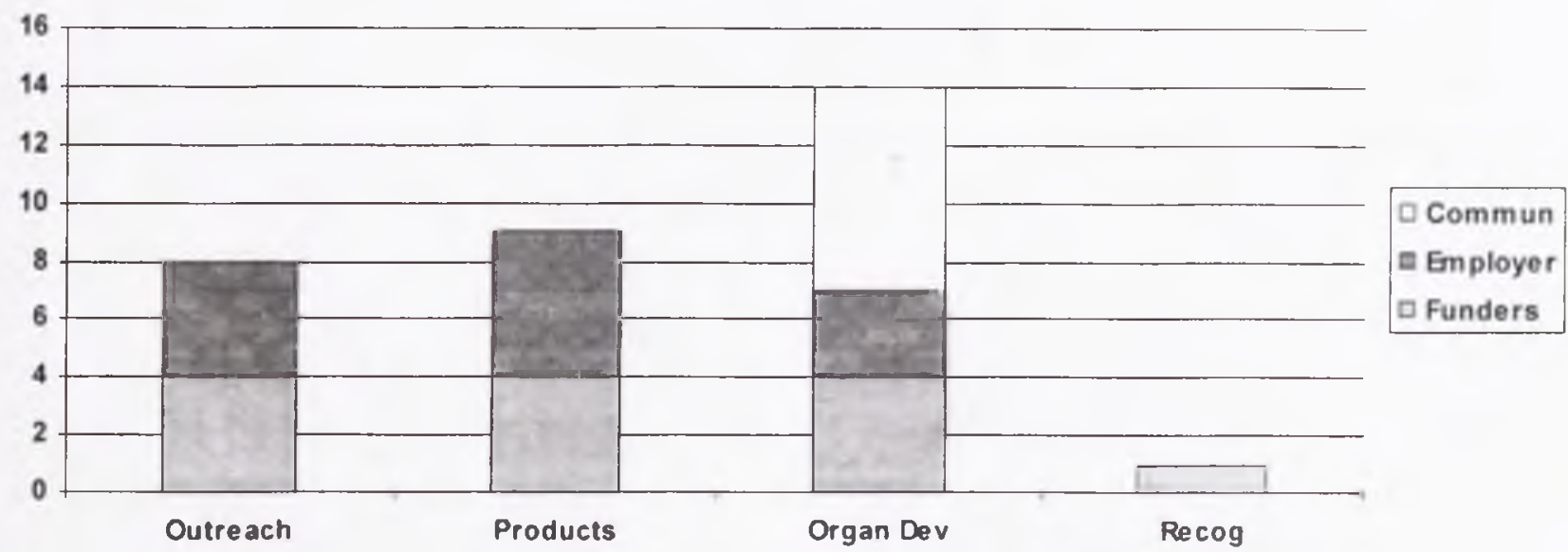

ries identified were that the graduates gained employment both in this country and abroad, that the college gained accreditation from formal, accepted bodies such as the Department of Education and the S A Nursing Council, and that the college has a good reputation in the community. egory or sub-category, the actual number of respondents who gave one or more example of a particular category is shown in the column sf or sample frequency. In order to interpret these findings more easily, the results have been computed into percentages to allow for comparison to ensure the relative size of 
each group is the same. As this is a qualitative study, the sample was not designed to be statistically valid and are provided only to assist interpretation. These results appear in table six and graphically per category/sub-category. Only the sample frequency is shown (see figures one to seven).

\section{Graphical representation of relative importance of values to internal customers}

Human resources are considered important by all strata, but particularly by the lecturers. The relative shortage of staff at present due to a moratorium on the filling of posts could have influenced the responses, although many respondents emphasized that the competency of the staff is important Education is a labour intensive industry, and particularly in the nursing colleges where educational technology is in its infancy. The allocation of $90 \%$ of the college budgets to personnel may be appropriate when considering the value placed on human resources by the respondents. As the administrative staff is responsible for the material and physical resources of the college, it is understandable that many of their responses were concentrated on this aspect. There is a growing realization of the importance of technology among the lecturers and administrative staff, but not among the students. It was apparent that in the colleges where they have not yet had access to tion and management of the college this is understandable. It is interesting that many more lecturers than managers mentioned this aspect. The managers are in a position to act on this aspect but the lecturers feel the effect of the quality of the human resource management. Again the lecturers are students consider management ethics more important than the managers. The responses within this category are an enigma. The fact that it is highly important to the students is understandable as they are immersed in the educational programme and it is their reason for being associated with the college. The lecturers, however, gave it virtually no significance, despite being employed to design, organize and present the educational programmes. It is possible that they assume a quality curriculum is implicit in a quality college.

Relationships within the college were important to all respondents, particularly the students and lecturers. Education is an inter-personal process so this is of little surprise. What is of concern, is the relative lack of responses regarding relationships with the external customers. This links closely to the small number of responses for practical learning facilities. Research was a small category, and should probably receive more attention in the colleges. There is a great deal of consensus regarding the importance of the products (graduates) of the colleges and also for the relatively new aspect of organizational development. The latter is probably explained by the

\section{Table 7: Summary of Community values}

\begin{tabular}{|l|l|}
\hline CATEGORY / SUB-CATEGORY & SOURCE \\
\hline STRUCTURE & \\
\hline Strategy: Transformation & BP, HE, SAQA, PS, SD \\
\hline Quality & BP, HE, SAQA, SD \\
\hline PROCESSES & \\
\hline Leadership: Policy development & BP, HE, SAQA, PS, FE, SD \\
\hline Human resource management & BP, HE, SAQA, PS, FE, NA, SD \\
\hline Management ethics & BP, HE, PS \\
\hline Relationships & BP, HE, PS \\
\hline RESULTS & \\
\hline Organizational development & BP, HE, SAQA, PS, FE, NA, SD \\
\hline
\end{tabular}

Key: BP - Batho Pele white paper, HE - Higher Education White Paper, SAQA - SA Qualifications Authority White Act, PS - White paper on Public Service Training and Education, FE - White paper on Further Education, NA - Nursing Act, SD - Skills Development Bill.

educational technology, they did not consider it significant, whereas in the college where a well-equipped computer based learning centre exists, the students did consider it important. It is of interest, and some concern that the practical learning facilities were not often cited by the internal customers, especially as the clinical training is of critical importance in nursing and the available facilities are currently under great pressure. As relatively more managers than the other respondents consider practical facilities important, there may be hope that this aspect will receive attention.

Human resource management was important to all strata except the students. As they are not involved in the organiza- fact that the colleges are currently in a process of transformation and therefore most aware of this aspect. The students place little importance on community outreach which is of concern.

The following graphs demonstrate the relative importance of the values in each category/sub-category to one another. Figure eight illustrates the sample frequency of responses. It can be clearly seen that human resources, both in terms of structure and management thereof, relationships with internal customers in the college, products of the college and organizational development are the most densely described categories followed closely by material resources. Figure nine which illustrates the results according to category frequency shows 
similar trends. The only significant changes are to products which is less densely described per category than per sample, and theoretical learning facilities which assumes comparatively less importance in the category frequency.

\section{External customers}

The external customers cited all the values cited by the internal customers. The relative frequency was, however, very different, due to the respondents' frame of reference. Figures eight to eleven reflect the sample frequency of the external customers. The funders and the employers were asked the same question as the internal customers. As a result their answers were specific to the nursing colleges, whereas the community values were extracted from documents. Strategy, policy development and organizational development were significant values. As the documents analyzed were transformational policy papers this was not surprising as the aim of the white papers is to develop strategy. The funders and employers, however, also found this significant. Relationships were identified by eleven of the twenty external customers. There was a good deal of consensus between the funders and the employers that human resources, management ethics, content of the curriculum and community outreach were important. Due to the fact that the community values were obtained in a different manner to those of the other external customers, their responses were not specific to quality in a nursing college, and although they were comfortably categorized within the system the values were more generic in nature and only six of the twenty one categories/ sub-categories were identified (see table seven).

With regard to strategy, the two aspects identified were transformation and quality. Transformation included redress, affirmative action openness of transparency, change management, management of diversity, empowerment and flexibility. Quality included standards of education, professionalism, value for money, adequacy, standards, cost-effectively, good planning, improved delivery and co-ordination. Strategy issues were covered in six of the seven documents. The Nursing Act which was the only document analyzed which was compiled before 1994 was the only one which did not specifically deal with this issue. All three of the leadership sub-categories, vis. human resource management, policy development and management ethics were found in the documents. Human resource management included staff development and labour relations. The latter were closely related to relationship issues such as cultural tolerance, sensitivity, promotion of liaison, consultation and representivity. Policy development issues included accessibility and governance. The latter mentioned academic autonomy, participation in governance, decentralization and integration as important values. Management ethics included accountability, transparency, dedication and service ethos. Leadership was covered by all seven documents. Management ethics specifically were identified in three of the documents and policy development in six. Governance was identified in four of the documents. Relationships were mentioned in very broad terms by nature of the documents where responsiveness, sensitivity and courtesy were identified as values. Relationships were identified in three of the documents. Organizational development included values of communication, quality control, conflict management and teamwork Organizational development was identified in all of the documents. The source of each of the categories and sub-categories can be seen in table ten.

\section{Conclusions}

The following conclusions are relevant:

- $\quad$ The main values related to quality in a nursing col -lege in Gauteng are structure, process and resultsbased.

- The main values of structure are human resources, material/physical resources, technology, theoretical learning facilities, practical learning facilities and strat -egy.

- $\quad$ The main process values are leadership, educational programme and relationships and research.

- $\quad$ The results which have an impact on quality in a nurs -ing college are community outreach, products of the college, organizational development and recognition in the community.

- $\quad$ The internal and external customers use the same val -ues to view quality but proportion different weight -ing to these values.

- The internal customers focus mainly on human re source management, internal relationships, organiza -tional development, human resources, products, ma -terial resources, technology theoretical learning fa -cilities and policy, in this order, while the external customers focus mainly on strategy, organizational development, policy, relationships, human resource management, human resources, management ethics, products and content of the curriculum.

- Ownership of the quality audit system can be assured through representation of internal and external cus -tomers in the development process.

\section{Recommendations}

It is recommended that the results of this study are used as the basis for the following:

- $\quad$ The devlopment of a quality audit system for nursing colleges in Gauteng.

- $\quad$ To develop the conceptual framework for the quality audit system, with an integrated literature control.

- $\quad$ The formulation of standards and performance indi -cators for the quality audit system for nursing col -leges in Gauteng.

\section{Acknowledgments}

All participants are thanked for their valuable contributions.

\section{References}

BALL, J 1991: Quality Assurance. London: Distance Learning Centre South Bank Polytechnic.

COVEY, SR 1994: The Seven Habits of Highly Effective People - powerful lessons in personal change. London: Simon and Schuster.

DE VOS, AS (ed) 1998: Research at Grass Roots. A primer for the caring professions. Pretoria: JL van Schaik. 
GREEN, D (ed) 1995: What is Quality in Higher Education? Buckingham: The Society for Research into Higher Education \& Open University Press.

HEIN, EC \& NICHOLSON, MJ (eds) 1994: Contemporary Leadership Behaviour. Philadelphia: JB Lippincott.

LEWIS, RG \& SMITH DH 1994: Total Quality in Higher Education. Florida: St Lucie Press.

LINCOLN, YS \& GUBA EG 1985: Naturalistic Inquiry. Beverly Hills: Sage.

MULLER, ME 1996: Nursing Dynamics. Johannesburg: Heinemann.

POPENOE, D 1977: Sociology. New Jersey: Prentice-Hall.

SOUTH AFRICA 1997: The white paper on Public Service Training and Education. Pretoria: State Press.

SOUTH AFRICA 1997: The white paper on Higher Education (Notice 712 of 1997 published in Government Gazette, Vol. 382, No. 17944. 18 April 1997). Pretoria: State Press.

SOUTH AFRICA 1997: Higher Education Act, No. 101 of 1997. Pretoria: State Press.

SOUTH AFRICA 1998: The white paper on transformation of Further Education and Training (Notice 2188 of 1998 published in Government Gazette, Vol. 399, No. 19281. 25 September 1998). Pretoria: State Press.

SOUTH AFRICA 1997: The white paper on transforming Public Service Delivery (Batho Pele white paper) (Notice 1459 of 1997 published in Government Gazette, Vol. 388, No. 18340. 1 October 1997). Pretoria: State Press.

SOUTH AFRICA 1995: The South African Qualifications Authority Act, (Act No. 58 of 1995). Pretoria: State Press.

SOUTH AFRICA 1998: The Nursing Act (No. 50 of 1978), as amended by No. 5 of 1995 and No. 19 of 1997. Pretoria: State Press.

SOUTH AFRICA 1998: The Skills Development Bill (B81 of 1998). Pretoria: State Press.

TESCH, R 1990: Qualitative Research: Analysis Types and Software Tools. Basingstoke: The Falmer Press.

THOMPSON, D (ed) 1995: The Concise Oxford Dictionary of Current English. Oxford: Claredon Press.

WALTERS, M (ed): The Performance Management Handbook. London: Institute of Personnel Development.

VAN DER WALDT, G \& DU TOIT, DFP: Managing for Excellence in the Public Sector. Kenwyn: Juta \& Co.

WEST-BURNHAM, J: Managing Quality in Schools. Effective Strategies for Quality Based School Improvement. London: Pitman. 